\title{
Litter Treatment Using Zeolite as a Management Protocol to Enhance Broiler Performance and Control Ammonia Emission in Broiler Production in the Humid Tropics of Nigeria
}

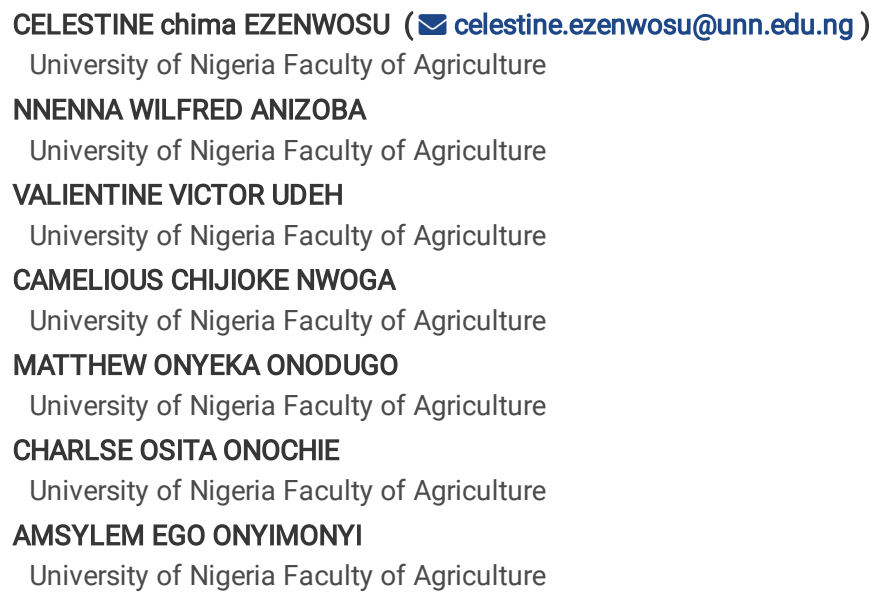




\section{Abstract}

A 9-week study was conducted to evaluate the effect of using zeolite as a litter management protocol to enhance broiler performance and control ammonia emission from litter. A total of 140 broiler birds (arbor acre) were used for the study. After brooding them together for 2 weeks as a way of stabilizing them, they were randomly assigned to 4 treatment groups labeled A-D in a completely randomized experimental design and each treatment was replicated 5 times with 7 birds per replicate. Treat2ment of the litter were as follows: treatment A litter (control) had no zeolite treatment, B (200g zeolite $\mathrm{kg}^{-3}$ litter), C (400g zeolite $\mathrm{kg}^{-3}$ litter), and D (600 g zeolite $\mathrm{kg}^{-3}$ litter). The experiment was divided into two phase. Starter phahse which lasted for 3 weeks and finisher phase lasted for 4 weeks. Feed and water were provided ad libitum Results showed significant differences $(P<0.05)$ in the birds' values for total feed intake, average daily feed intake, total beyody weight, average daily weight gain, final body weight and feed conversion ratio in both phases in favor of treatment groups. The litter chemical analysis showed significant differences $(P<0.05)$ in the bird's mean values for mo5isture, uric acid, $\mathrm{pH}$, phosphorous, ammonium nitrate, total volatile fatty acid, ammonium sulfate, ammonia, nitrogen, and ash among the study groups in both phases. Difference in litter microbial load values among the treatments were also significant $(\mathrm{P}<0.05)$. In conclusion, litter treatment using zeolite as a management protocol to enhance broiler performance and control ammonia emission was able to enhance performance of the birds by exerting diminutive effect on the precursors and microbial activities that are involve in ammonia production from the litter. It is therefore recommended that farmers can adopt this litter management protocol to reduce ammonia emissions in broiler houses without negatively affecting the growth of the birds.

\section{Introduction}

According to recent projections, the world human population will likely attain eight billion. Also, according to United Nations Population Division and United Nations Department of Economic and Social Affairs (2010) the global human population by 2042 will be expected to rise to nine billion. As of Wednesday, October 23, 2019, Nigeria population was about 202,559,797million (World meters, 2019).

This escalating human population might need a doubling and sustainable source of farm animal protein and provision of sustainable source of farm animal protein that will meet the protein need of the rising global human population calls $f$ or the production of all classes of poultry meat such as chicken and turkey. However, investing meaningfully in poultry production will help to reduce hunger and poverty which are currently ravaging the increasing human population globally. FAO (2010) revealed that poultry sector is among the top sectors that provide various sources of animal proteins for human utilization. Poultry are most inexpensive source of farm animal protein, contributing meaningfully to the rising demand for animal food products globally (Farrell, 2013). During the last two decades, poultry industry was the greatest dynamic meat sector, displaying the utmost growth of the entire meat sectors as mirrored in world consumption. According to Adene (1989) and Moore et al. (1996) majority of organizations and individuals globally depends on poultry sector for considerable portion of their revenue and protein which is low in cholesterol

However, poultry sector despite its contribution in the mitigation of poverty and hunger is still faced with increasing environmental challenges. One of these outstanding environmental challenges is the problem of odor production which ammonia gas is the most common. Ammonia is a leading upsetting gas that emanates from poultry litter. Ammonia gas is a product of degradation or putrefaction of protein-rich substrates such as animal manure by microbes (Munk et al., 2017; Mata-Alvarez et al., 2014). Ammonia gas production is normal part of poultry production, but, it potentially undermines the sustainable development of the industry, cause environmental pollution and contribute to the global climate change. According to Meda et al. (2011) ammonia gas generated from the litter has numerous harmful impacts on the environment. Acidification of lands and water surfaces which is capable of causing injuries on vegetation and reduction in variety of plant and animal life in the world or in a particular habitat is enhanced by high atmospheric ammonia concentration. Work of Sanjay et al. (2006) confirms that high ammonia content of litter is capable of causing an increase in fertilizer value and thereby, leading to environmental pollution that will cause health hazards to neighbors. Ammonia production contributes strongly to the high rate of atmospheric nitrogen deposition (Van et al., 1982, Apsimon et al., 1987). Some of the consequences of high ammonia concentration on birds are: respiratory tract infections, reduction in the intake of feed, eye blindness and decrease in productivity, (Wheeler et al., 2004).

Therefore, the lessening of these negative effects of ammonia on poultry performance and on our environment calls for an application of good litter management protocol that will create a friendly atmosphere in the poultry house via the reduction of ammonia production from the litter.

However, one of the litter management protocols that will help to reduce high ammonia production from the litter is the treatment of litter with zeolite. Zeolite according to Amon et al. (1997) has an open micro channel in its crystal structure that enables the assimilation of $\mathrm{H}_{20}$ and gases, such as ammonia. High production of odorous gases most especially ammonia that cause environmental degradation and negatively affect performance of birds takes place when the litter pH and moisture are high (Reece et al., 1979; Elliott and Collins, 1982). High litter pH (alkalinity) and moisture encourage microbial proliferation and degradation of litter. The lower the litter moisture and $\mathrm{pH}$, the lower the ammonia production because of decreased microbial degradation of litter. Reduction of litter $\mathrm{pH}$ and moisture which are among the major culprits in ammonia production from the litter can be achieved by treating the litter with zeolite. According to research, zeolite has been utilized to lessen the emanation of poisonous gases such as ammonia (Amon et al., 1997). It has been used as a litter constituent (Ullman et al., 2004). Treatment of litter with zeolite creates an unfavorable environment for microbial litter degradation that are responsible for odor production such as ammonia from the litter and thus, making the birds to escape the deleterious effect of these odorous gases on their performance in terms of body weight increase as a result of decreased intake of food or feed, poor feed conversion and utilization in the body. Treatment of litter with zeolite helps to ameliorate the litter moisture (Schneider et al., 2016) and thus, risk of disease spread from the litter to the birds is reduced. Schneider et al. (2016) reported that the incorporation of ten percent zeolite to the litter decreased moisture litter content and rate of volatilization of ammonia. Recent research work relate zeolites to the conservation of surroundings as a result of their ability in retaining gaseous pollutants such as ammonia emanating from farm animal production (Zimmermann, 2014; Bujnak et al., 2015). According to Obayelu (2010) there has been public increasing intolerance of odor from livestock production facilities, therefore this study is designed to investigate the growth performance, liter chemical compositions and microbial loads of broiler birds reared on different levels of zeolite treated litter during starter and finisher growth phase.

Page 2/15 


\section{Materials And Methods Study area and duration}

The study was carried out at the Poultry Unit of the Department of Animal Science Teaching and Experimental Farms, University of Nigeria; Nsukka. The study was carried out at the Department of Animal Science Teaching and Experimental Farms, Poultry Section of the University of Nigeria, Nsukka Enugu State. It is located on latitude $6^{0} 25 \mathrm{~N}$ and longitude $7^{0} 24 \mathrm{E}$ at an altitude of $430 \mathrm{~m}$ above sea level (Breinholt et al., 1981). The average maximum ambient temperature ranges from $33^{\circ} \mathrm{C}$ and $37^{\circ} \mathrm{C}$ (Okonkwo and Akubuo, 2007). The annual rainfall ranges from $1567.05 \mathrm{~mm}-1846.98 \mathrm{~mm}$ (Metrological Center, Crop Science Department, University of Nigeria, Nsukka Enugu State). The study lasted for 9 weeks.

\section{Source of the zeolite and feed ingredients}

The chemical that was used in the litter treatment was zeolite. The zeolite was purchased from a trusted chemical dealer in Nsukka Urban and Enugu Nigeria. The zeolite which was in a powdered form was kept at room temperature as specified by the manufacturer. Ingredients that were used in the feed formulation for both starter and finisher ration were as follows: $10 \%$ concentrate purchased from Agro Bar-Magen Enugu. The 10\% concentrate contain the following ingredients: fat, fibre, lysine, Met-Cystein, methionine, cysteine, calcium, phosphorous and other feed stuffs such as yellow maize, soybean meal, wheat offal, red oil that were used in the mixing of the concentrate were purchased from an accredited feed stuff dealer in Nsukka Urban Enugu State Nigeria. Inclusion levels of these feed stuffs as given by Agro Bar-Magen were strictly followed.

\section{Experimental diet}

The compositions and proximate compositions of the diets are shown in Table $\mathbf{1}$ and $\mathbf{2}$ for both starter and finisher ration. Experimental diets for the starter and finisher were computed to contain $23.00 \%$ and $20.00 \%$ crude protein and Metabolizable Energy content of 28Mcal $/ \mathrm{kg} \mathrm{ME}$ and $3.0 \mathrm{Mcal} / \mathrm{kg} \mathrm{ME}$ respectively. Samples of the experimental diets were analyzed for their proximate compositions using (AOAC, 2006).

Table 1

Percentage composition of experimental diets

\begin{tabular}{|lll|}
\hline Ingredients & Starter (\%) & Finisher (\%) \\
Maize & 46.60 & 51.00 \\
Wheat offal & 15.00 & 15.20 \\
Soya bean meal & 30.00 & 24.40 \\
Lysine & 0.30 & 0.20 \\
Methionine & 0.35 & 0.20 \\
Met-Cyst & 0.25 & 0.20 \\
Red oil & 1.80 & 2.00 \\
Phosphorous & 0.70 & 0.80 \\
Fiber & 1.00 & 1.40 \\
Calcium & 3.10 & 3.60 \\
Fat (plants and animal fats) & 0.90 & 1.00 \\
Total & 100 & 100 \\
Calculated compositions & & 3.00 \\
Crude protein (\%) & 23.00 & 3.20 \\
Crude fiber (\%) & 4.20 & 3.00 \\
Ether extract (\%) & 3.80 & 20.00 \\
Energy (Kcal/KgME) & 2823.67 & 3.00 \\
\hline
\end{tabular}




\begin{tabular}{|c|c|c|}
\hline \multicolumn{3}{|c|}{$\begin{array}{c}\text { Table:2 } \\
\text { Proximate compositions of experimental diets }\end{array}$} \\
\hline Parameters & Starter & Finisher \\
\hline Moisture & 11.90 & 12.19 \\
\hline Dry matter & 88.10 & 87.81 \\
\hline Ash & 17.42 & 18.20 \\
\hline Crude fibre & 4.39 & 4.96 \\
\hline Ether extract & 3.83 & 4.17 \\
\hline Crude protein & 22.89 & 20.12 \\
\hline Nitrogen free extract & 39.58 & 39.87 \\
\hline Met.Energy Kcal.kg-1 & 2799.99 & 2998.69 \\
\hline
\end{tabular}

\section{Experimental layout}

The experiment was done using completely Randomized Design (CRD). The experiment involved four treatments of 35 birds. Each treatment was replicated 5 times with 7 birds per replicate. The distributions of birds are shown in Table 3 .

Table 3

Experimental Layout

\begin{tabular}{|lllll|}
\hline & & & \multicolumn{2}{r|}{ Treatments } \\
\hline Replicates & A & B & C & D \\
\hline R3 & 7 & 7 & 7 & 7 \\
R2 & 7 & 7 & 7 & 7 \\
\hline R3 & 7 & 7 & 7 & 7 \\
R4 & 7 & 7 & 7 & 7 \\
R5 & 7 & 7 & 7 & 7 \\
\hline Total & 140 & 140 & 140 & 140 \\
\hline
\end{tabular}

The birds were randomly placed in various replicates and treatments. Each treatment received zeolite treatment at varying level as follows: Treatment $\mathrm{A}$ : $0 \mathrm{~g}$ zeolite $\mathrm{kg}^{-3}$ litter, treatment B: $200 \mathrm{~g}$ zeolite $\mathrm{kg}^{-3}$ litter, treatment C: $400 \mathrm{~g}$ zeolite $\mathrm{kg}^{-3}$ litter and treatment D: $600 \mathrm{~g}$ zeolite $\mathrm{kg}^{-3}$ litter respectively.

\section{Experimental birds and management}

Total of 140 day old broiler birds were used for the study. This study was divided into two phases (starter and finisher phase). In the first two week of life, the birds were brooded together before they were weighed and randomly placed in various replicate per treatments to begin the starter phase of the experiment which lasted for 3 weeks. At the end of the starter phase, the birds were reweighed again and randomly placed in the various replicates and treatment to start the finisher phase of the work that lasted for 4 weeks. Prior to the arrival of the birds from the hatchery, the brooding house was cleaned with soap and disinfected with strong disinfectant after which wood shavings were spread. The pen was pre-heated few hours before the arrival of the birds. The pre-heating was to achieve a nice brooding environment that would enhance bird's activities. Feeding troughs and drinkers were also procured, disinfected and strategically positioned. Clean drinking water and feed were made ready before the arrival of the birds. Timely vaccination and drugs were administered appropriately.

\section{Litter treatment}

The zeolite powder and the litter materials (wood shavings) were properly mixed together in all the replicates in the various treatments. The treatment of litter with zeolite was done once throughout the trial periods.

\section{Collection of data}

The following data were collected: 


\section{Initial body weight and body weight gain}

At the beginning of each phase of this experiment, the birds were weighed and also weighed on weekly basis throughout the experimental periods. At the end of the previous week, weight measured was subtracted from that of the present week in order to get the body weight gained for the week. A box on a top pan balance was used to weigh the birds and it was done in batches.

\section{Feed intake (g)}

On each day throughout the experimental periods, feed was weighed before being given to the birds. Then, the difference between the feed provided the preceding day and left over feed in the feeding trough the next morning was divided with the number of birds in each replicate in order to get daily feed intake per bird for each replicate.

\section{Average daily feed intake (ADFI)}

This was obtained by dividing the total feed intake of birds with the number of days the feeding trial lasted.

\section{Average daily weight gain (ADWG)}

This was obtained by dividing total weight gained per bird per replicate with the number of days the feeding trial lasted.

\section{Total feed intake (TFI)}

This was calculated by summing the daily feed intakes of the birds throughout the trial period.

\section{Final body weight (FBW)}

Weights of the birds at end of trial periods.

Feed conversion ratio $(\mathrm{FCR})=$ Feed consumed $(\mathrm{g})$ Weight gain $(\mathrm{g})$

\section{Litter chemical properties measured were as follows:}

\begin{tabular}{ll} 
Moisture & Nitrogen \\
\hline $\mathrm{pH}$ & Uric acid \\
\hline Ammonium nitrate & Ash \\
\hline Total volatile fatty acids & \\
\hline Ammonium sulfate & \\
\hline Ammonia & \\
\hline
\end{tabular}

Phosphorous

Mortality

Mortality was chronicled as it occurred and birds that died were taken to the post mortem room of the Veterinary Pathology Laboratory, University of Nigeria, Nsukka for post-mortem examination to ascertain the cause of their deaths.

\section{Procedure for chemical analysis of the litter}

\section{Moisture determination was done using oven method}

\section{Moisture $(\%)=\underline{\text { Weight of dried sample } \times 100}$ Fresh weight used $(2 \mathrm{~g})$}




\section{Nitrogen determination}

Determination of nitrogen in the sample was done by using kjedahl micro method (Pearson, 1976). The technique involves sample digestion, digest distillation and titration of distillate.

\section{Ammonia determination}

Ammonia was ascertained by precipitation with sodium tetra phenyl borate as it is sparingly

soluble in ammonium tetra phenyl borate.

\section{Uric acid determination}

Uric acid was determined by multiplying the percentage nitrogen by factor 3

\section{Determination of ammonium sulphate}

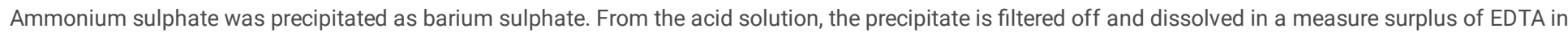
the presence of aqueous ammonia.

Ammonium sulphate $/ P P M=T \times N \times E \times 1000$ Volume of sample utilized.

Where $\mathrm{T}$ = Titre value, $\mathrm{M}=$ Molarity of the standardized EDTA

$\mathrm{E}=$ Equivalent weight

\section{Phosphorus determination}

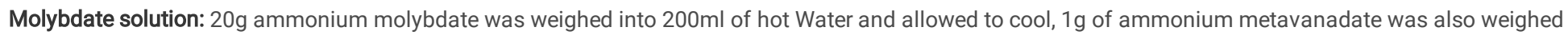

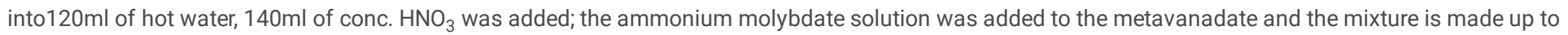
$1 \mathrm{dm}^{3}$ with distilled water.

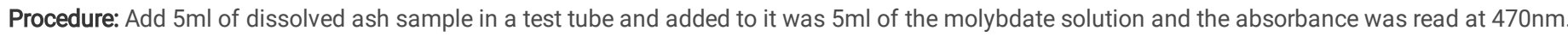
Standard curve was used to calculate the Concentration.

\section{Volatile fatty acid determination}

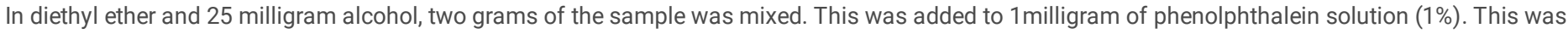

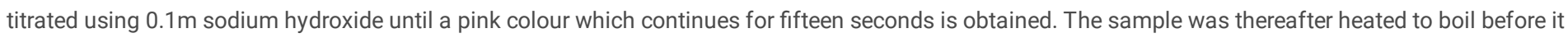
titrated again and the difference between the first and second titrations was calculated as the final titre value.

Volatile Acid Value $=$ Titre $X 5.61$ Weight of sample used

Volatile Fatty acid= Volatile Acid value.

\section{$\mathrm{pH}$ determination}

The $\mathrm{pH}$ of the sample was determined using $20 \%$ of the sample.

\section{Experimental design}

The experiment was executed using Completely Randomized Design (CRD).The experimental model of the Completely Randomized Design:

$\mathrm{Xij}=\mu+\mathrm{T}_{1}+\sum \mathrm{ij}$

Where, $\mathrm{Xij}=$ any observation or measurement taken

$\mu=$ population mean

$T_{1}=$ treatment effect

$\sum \mathrm{ij}=$ experimental error 
$\mathrm{i}=$ number of treatments

j=number of replicates

\section{Statistical Analyses}

Data generated were subjected to the analysis of variance (ANOVA) in CRD using statistical package (SPSS, 2003) Windows version 8.0. Mean differences were separated using Duncan's New Multiple Range Test (Duncan, 1955) as outlined by Obi (2002).

\section{Results}

\section{Growth performance of the birds during the starter phase}

The result of growth performance of broiler starter reared on different levels of zeolite treated litter is presented in Table 4. Treatment of the litter with zeolite caused significant $(P<0.05)$ differences among the treatment means in total feed intake, total weight gain, final body weight, average daily feed intake, average daily weight gain, feed conversion ratio. Total feed intake of treatment $A$ and $C$ were similar $(P<0.05)$, but significantly higher than 1970.67 and 1871.33 that were observed for birds on treatment $B$ and $C$ that were also the same $(P>0.05)$. Average daily feed intake followed the same trend as observed for total feed intake. Total weight gain values of treatment $A$ and $B$ were the same $(P<0.05)$, but significantly lower and different from values of 1576.67 and 1803.33 that were recorded in treatment $C$ and $D$ respectively. Values of final body weight and average daily weight gain among the treatments followed the same trend as observed for total feed intake. Feed conversion ratio values of treatment $D$ and $C$ were similar $(P>0.05)$ but lower than values observed for birds on treatment $B$ and $A$ that were the same also.

Table 4

Growth performance of broiler starter reared on different levels of zeolite treated litter

\begin{tabular}{|c|c|c|c|c|c|c|}
\hline Parameters (g) & A & B & C & D & SEM & P-values \\
\hline Initial body weight & 550.67 & 551.67 & 547.67 & 552.00 & 2.81 & 0.962 \\
\hline Total Feed Intake & $1871.33^{b}$ & $1970.67^{b}$ & $2351.33^{a}$ & $2565.67^{a}$ & 92.94 & 0.002 \\
\hline Total Weight Gain & $1080.67^{c}$ & $1150.00^{c}$ & $1576.67^{\mathrm{b}}$ & $1803.33^{\mathrm{a}}$ & 90.77 & 0.000 \\
\hline Final Body Weight & $1631.33^{c}$ & $1701.67^{c}$ & $2124.33^{b}$ & $2355.33^{a}$ & 90.76 & 0.000 \\
\hline Feed conversion ratio & $1.73^{\mathrm{a}}$ & $1.71^{\mathrm{a}}$ & $1.49^{b}$ & $1.41^{b}$ & 0.05 & 0.023 \\
\hline Average daily feed intake & $89.11^{b}$ & $93.83^{b}$ & $111.97^{a}$ & $121.63^{a}$ & 4.37 & 0.020 \\
\hline Average daily weight gain & $51.46^{\mathrm{c}}$ & $54.76^{\mathrm{C}}$ & $75.07^{b}$ & $85.87^{a}$ & 4.32 & 0.000 \\
\hline
\end{tabular}

abcd means on the same row with different superscript are significantly $(P<0.05)$ different

Treatment A: $0 \mathrm{~g}$ zeolite per $3 \mathrm{~kg}$ litter, Treatment B: $200 \mathrm{~g}$ zeolite per $3 \mathrm{~kg}$ litter, Treatment C: $400 \mathrm{~g}$ zeolite per $3 \mathrm{~kg}$ litter, Treatment D: $600 \mathrm{~g}$ zeolite per $3 \mathrm{~kg}$ litter.

\section{The growth performance of the birds during the finisher phase}

The growth performance of broiler finishers reared on different levels of zeolite treated litter is shown in Table 5. Treatment of the litter with zeolite caused significant $(\mathrm{P}<0.05)$ differences among the treatment means in total feed intake, total weight gain, final body weight, average daily feed intake, average daily weight gain, feed conversion ratio. Total feed intake of treatment $D$ and $A$ were similar $(P>0.05)$, but higher than the 4357.67 and 4403.67 that were observed for birds on treatment $B$ and $A$ that were the same also. Values of final body weight and average daily feed intake followed the same trend as observed for total feed intake. Total weight gain of treatment $A$ and B were similar $(P>0.05)$, but significantly lower than the values of 1876.67 and 2150.00 observed for birds on treatment $C$ and $D$. Average daily feed intake followed the same trend as observed for total weight gain among the treatments. Feed conversion ratio values of treatment $D$ and $C$ were similar $(P>0.05)$, but significantly lower than the 2.96 and 3.13 observed for birds on treatment $B$ and $A$. 
Table 5

Growth performance of broiler finisher reared on different levels of zeolite treated litter

\begin{tabular}{|c|c|c|c|c|c|c|}
\hline Parameters(g) & A & B & C & D & SEM & P-values \\
\hline Initial body Weight & 2113.67 & 2094.33 & 2098.67 & 2109.00 & 24.25 & 0.999 \\
\hline Total Feed Intake & $4403.67^{b}$ & $4357.67^{b}$ & $4800.00^{\mathrm{a}}$ & $4986.67^{a}$ & 87.25 & 0.002 \\
\hline Total Weight Gain & $1393.33^{c}$ & $1470.00^{c}$ & $1876.67^{b}$ & $2150.00^{a}$ & 95.42 & 0.000 \\
\hline Final Body Weight & $3573.67^{b}$ & $3551.00^{b}$ & $3975.33^{a}$ & $4259.00^{a}$ & 97.84 & 0.002 \\
\hline Feed conversion ratio & $3.13^{\mathrm{a}}$ & $2.96^{\mathrm{a}}$ & $2.56^{b}$ & $2.39^{b}$ & 0.09 & 0.000 \\
\hline Average daily feed intake & $157.27^{\mathrm{b}}$ & $155.63^{b}$ & $171.42^{\mathrm{a}}$ & $178.09^{a}$ & 3.12 & 0.002 \\
\hline Average daily weight gain & $49.76^{c}$ & $52.43^{c}$ & $66.90^{\mathrm{b}}$ & $73.94^{\mathrm{a}}$ & 3.11 & 0.000 \\
\hline
\end{tabular}

abcd means on the same row with different superscript are significantly $(P<0.05)$ different

Treatment A: 0g zeolite per $3 \mathrm{~kg}$ litter, Treatment B: $200 \mathrm{~g}$ zeolite per $3 \mathrm{~kg}$ litter, Treatment C: $400 \mathrm{~g}$ zeolite per $3 \mathrm{~kg}$ litter, Treatment D: $600 \mathrm{~g}$ zeolite per $3 \mathrm{~kg}$ litter.

\section{Chemical litter compositions during the starter growth phase}

The result of the chemical compositions of different levels of zeolite treated litter during the starter growth phase is presented in Table 6 . Treatment of litter in this study significantly $(\mathrm{P}<0.05)$ affected the nitrogen, ammonia, ammonium nitrate, ammonium sulfate, $\mathrm{pH}$, moisture, phosphorus, uric acid, total volatile fatty acid and ash values among the treatments. Nitrogen value of treatment $A$ and $B$ were similar $(P>0.05)$, but significantly lower than 2.47 and 3.13 recorded in treatment $C$ and $D$ respectively. Phosphorous and uric acid values followed the same trend observed in nitrogen values among the treatments. Ammonia values of treatment $D, C$ and $B$ were similar $(P>0.05)$, but significantly lower than the value of 5.13 recorded in treatment $A$ (control). Ammonium nitrate value followed the same trend observed in ammonia values. Ammonium sulfate values of treatment $A$ and $B$ were the same, but significantly lower than the values of 6.64 and 6.06 recorded in treatment $C$ and $D$ respectively. $p H$ values of treatment $D$ and $C$ were the same ( $P>0.05)$, but significantly lower than the values of 6.16 and 7.67 recorded in treatment $A$. Moisture value of treatment $A$ was significantly higher than the values of $6.87,4.80$ and 4.06 recorded in treatment $B, C$ and $D$ respectively. Volatile fatty acid values among the treatment followed the same trend observed in moisture values among the treatments. Treatment $D$ ash value was the highest compared to the values of $17,14.67$ and 13 that were recorded in treatment $C, B$ and $A$ respectively.

Table 6

Result of the Chemical compositions of different levels of zeolite treated litter during the starter growth phase

\begin{tabular}{|c|c|c|c|c|c|c|}
\hline Parameters(\%) & A & B & C & D & SEM & P-values \\
\hline Nitrogen & $1.53^{\mathrm{c}}$ & $1.48^{\mathrm{c}}$ & $2.47^{b}$ & $3.13^{\mathrm{a}}$ & 0.22 & 0.000 \\
\hline Ammonia & $5.13^{a}$ & $2.79^{b}$ & $1.81^{\mathrm{bc}}$ & $1.60^{c}$ & 0.44 & 0.000 \\
\hline Ammonium nitrate & $8.29^{a}$ & $6.47^{b}$ & $4.50^{c}$ & $3.88^{c}$ & 0.55 & 0.001 \\
\hline Ammonium sulfate & $14.06^{\mathrm{a}}$ & $11.23^{\mathrm{a}}$ & $6.64^{b}$ & $6.06^{b}$ & 1.07 & 0.000 \\
\hline $\mathrm{pH}$ & $7.67^{a}$ & $6.16^{b}$ & $4.34^{c}$ & $3.47^{c}$ & 0.52 & 0.001 \\
\hline Moisture & $7.83^{a}$ & $6.87^{b}$ & $4.80^{c}$ & $4.06^{d}$ & 0.47 & 0.001 \\
\hline Phosphorous & $0.42^{c}$ & $0.56 b^{c}$ & $0.67^{b}$ & $1.05^{\mathrm{a}}$ & 0.67 & 0.001 \\
\hline Uric Acid & $3.56^{c}$ & $4.16^{c}$ & $6.65^{b}$ & $10.45^{\mathrm{a}}$ & 6.21 & 0.000 \\
\hline TVA & $5.18^{a}$ & $4.26^{b}$ & $3.11^{c}$ & $2.54^{d}$ & 3.77 & 0.000 \\
\hline Ash & $13.00^{d}$ & $14.67^{c}$ & $17.00^{\mathrm{b}}$ & $18.67^{a}$ & 15.83 & 0.000 \\
\hline
\end{tabular}

\section{Chemical litter compositions during the finisher growth phase}

The result of the chemical compositions of different levels of zeolite treated litter during the finisher growth phase is presented in Table 7. Ammonium nitrate values of treatment $D$ and $C$ were the same $(P>0.05)$, but significantly lower than the values of 13.94 and 15.40 recorded in treatment $B$ and $A$ respectively. Values of ammonium sulfate, $\mathrm{pH}$, and moisture among the treatment followed the same trend observed in ammonium sulfate. Uric acid value of treatment $\mathrm{D}$ was significantly higher than the values of $13,10.12$ and 8.37 recorded in treatment C, B and A respectively. Volatile fatty acid value content of treatment A was significantly higher than the values of $6.33,4.90$ and 3.74 recorded in treatment $B, C$ and $D$ respectively. Values of ash of treatment $A$ and $B$ were similar 
$(P>0.05)$, but significantly lower than the values of 26.38 and 28.53 recorded in treatment $C$ and $D$ respectively. Ammonia value of treatment $A$ was significant higher than values recorded in treatment $B, C$ and $D$. Nitrogen values of treatment $A$ and $B$ were the same $(P>0.05)$, but lower than the values of 5.73 and 7.33 recorded in treatment $\mathrm{C}$ and $\mathrm{D}$ respectively.

Table 7

Result of the chemical compositions of different levels of zeolite treated litter during the finisher growth phase.

\begin{tabular}{|c|c|c|c|c|c|c|}
\hline Parameters (\%) & A & B & C & D & SEM & p-values \\
\hline Ammonium nitrate & $15.40^{\mathrm{a}}$ & $13.94^{\mathrm{b}}$ & $12.57^{c}$ & $12.00^{c}$ & 0.43 & 0.001 \\
\hline Ammonium sulfate & $19.77^{a}$ & $17.91^{\mathrm{ab}}$ & $16.00^{\mathrm{bc}}$ & $15.00^{c}$ & 0.61 & 0.003 \\
\hline $\mathrm{pH}$ & $9.33^{a}$ & $7.77^{b}$ & $5.53^{c}$ & $4.90^{c}$ & 0.55 & 0.000 \\
\hline Moisture & $13.17^{a}$ & $11.83^{b}$ & $9.00^{c}$ & $8.67^{c}$ & 0.60 & 0.000 \\
\hline Phosphorous & 0.26 & 0.22 & 0.24 & 0.25 & 0.01 & 0.592 \\
\hline Uric Acid & $8.37^{d}$ & $10.12^{\mathrm{c}}$ & $13.00^{\mathrm{b}}$ & $16.67^{a}$ & 0.97 & 0.000 \\
\hline VFA & $8.33^{a}$ & $6.33^{b}$ & $4.90^{\mathrm{c}}$ & $3.74^{d}$ & 0.53 & 0.000 \\
\hline Ash & $21.67^{b}$ & $23.45^{\mathrm{b}}$ & $26.38^{a}$ & $28.53^{a}$ & 0.86 & 0.001 \\
\hline Ammonia & $12.95^{\mathrm{a}}$ & $8.16^{b}$ & $6.35^{c}$ & $4.87^{d}$ & 0.56 & 0.000 \\
\hline Nitrogen & $3.30^{c}$ & $4.07^{c}$ & $5.73^{\mathrm{b}}$ & $7.33^{\mathrm{a}}$ & 0.48 & 0.000 \\
\hline
\end{tabular}

${ }^{\text {abcd }}$ means on the same row with different superscript are significantly $(P<0.05)$ different

Treatment A: 0g zeolite per $3 \mathrm{~kg}$ litter, Treatment B: $200 \mathrm{~g}$ zeolite per $3 \mathrm{~kg}$ litter, Treatment C: $400 \mathrm{~g}$ zeolite per $3 \mathrm{~kg}$ litter, Treatment D: $600 \mathrm{~g}$ zeolite per $3 \mathrm{~kg}$ litter.

\section{Microbial load during the starter growth phase}

The result of the effect of different levels of zeolite treated litter on microbial load during the starter growth phase is presented in Table 8. Total viable count values of treatment $D, C$ and $B$ were similar $(P>0.05)$, but significantly lower than the value of 236666666.67 recorded in treatment $A$. Mold values among the treatment follows the same trend as observed for total viable counts. Coli form values of treatment $A$ and $B$ were the same ( $>0.05)$, but significantly lower than values recorded in treatment $C$ and $D$ respectively.

Table 8

Result of the effect of different levels of zeolite treated litter on microbial load during the starter growth phase

\begin{tabular}{|c|c|c|c|c|c|c|}
\hline $\begin{array}{l}\text { Parameters } \\
\text { (cfu/g) }\end{array}$ & $\mathrm{T} 1$ & T2 & T3 & $\mathrm{T} 4$ & SEM & P-Value \\
\hline Trc & $236666666.67^{a}$ & $50000000.00^{\mathrm{b}}$ & $133333333.33^{b}$ & $11000000.00^{\mathrm{b}}$ & 16196005.87 & 0.004 \\
\hline Coli form & $5733.33^{a}$ & $5000.00^{\mathrm{ab}}$ & $4133.33^{\mathrm{bc}}$ & $3266.67^{c}$ & 313.66 & 0.004 \\
\hline Mold & $100.00^{a}$ & $22.33^{b}$ & $16.00^{\mathrm{b}}$ & $11.00^{\mathrm{b}}$ & 14.92 & 0.003 \\
\hline
\end{tabular}

\section{Microbial load during the finisher growth phase}

The result of the effect of different levels of zeolite treated litter on microbial load during the finisher growth phase is presented in Table 9 . Coli form value of treatment $B, C$ and $D$ were the same $(P>0.05)$, but significantly lower than value of 6055.67 recorded in treatment $A$. Mold values among the treatment followed the same trend observed in coli form values among the treatments. 
Table 9

Effect of different levels of zeolite treated litter on litter microbial load during the finisher growth phase.

\begin{tabular}{|llllll}
\hline Parameters (cfu/g) & T1 & T2 & T3 & T4 & SEM \\
\hline Tvc & 270000000.00 & 226666666.67 & 220000000.00 & 160000000.00 & 16626846.37 \\
\hline Coli form & $6055.67^{\mathrm{a}}$ & $5200.00^{\mathrm{b}}$ & $4196.33^{\mathrm{b}}$ & $4415.00^{\mathrm{b}}$ & 0.115 \\
\hline Mold & $373.33^{\mathrm{a}}$ & $253.33^{\mathrm{b}}$ & $184.67^{\mathrm{b}}$ & $183.33^{\mathrm{b}}$ & 4.043 \\
\hline $\begin{array}{l}\text { abc Means on the same row with different superscript are significantly (P<0.05) different. } \\
\text { Tvc: Total viable counts, cfu: Colony forming unit. Treatment A: Og zeolite per 3kg litter, Treatment B: 200g zeolite per 3 kg litter, Treatment C: 400g zeolite } \\
\text { per 3kg litter, Treatment D: 600g zeolite per 3kg litter. }\end{array}$ \\
\hline
\end{tabular}

\section{Discussion}

\section{Effect of different levels of zeolite treated litter on growth performance of broiler starter and finisher}

Table 4 and 5 shows the results of the effect of zeolite treated litter on growth performance of broiler starter and finisher. From the results, highest $(P<0.05)$ body weight gain was recorded in favor of birds reared on zeolite treated litter. Body weight gain significantly increased $(P<0.05)$ as the level of zeolite in the litter increased. This is an indication that high ammonia production which is known to have negative effect on feed intake, weight gain and productivity (Wheeler et al., 2004; Wang et al., 2014) decreased significantly in treatment groups compared with the control treatment (Table 6 and 7). This agrees with the study of Sarıca et al. (1996) who applied zeolite to the litter and observed a significant variation in live weight gain in favor of birds reared on treated litter and disagreed with the findings of Altan et al. (1998) who used zeolite to treat litter and reported no statistical variations in the live body weight gain of birds among the treatments.

Birds reared on treatment $A$ (control) recorded the lowest $(P<0.05)$ weight gain. This could be attributed to the high ammonia production recorded in treatment A (Table 6 and 7). Beker et al. (2004) reported that ammonia in poultry facilities decreases performance of birds. Birds reared in an environment with increased ammonia production will experience reduced feed intake because of its choking and irritant nature. Broiler feed intake and feed efficiency has been revealed to reduce during exposure to increase levels of ammonia (Miles et al., 2002). When feed intakes reduce, weight gain tends to reduces also.

Ammonia causes vision problem in birds (Wang et al., 2014). According to Kristensen and Wathes (2000) exposure of birds to high ammonia concentration resulted in eye damage in the form of keratoconjunctivitis. After eye damage has taken place, birds may have complexity in finding water and feed.Vision problem caused by high ammonia gas production in the pen can limit the movement of birds in the pen and thereby resulting to reduced feed intake and weight gain as observed in control treatment.

Reduced $(P<0.05)$ weight gain observed in birds reared on control treatment compared to the treatment group could also be attributed to effect of ammonia on birds as a good stressor. Stress affects feed intake and body weight gain in farm animals. Induced oxidative stress can culminate into decreased productivity (St-Pierre et al., 2003). When an animal is stressed, productivity tends to reduce. Aziz and Barnes (2009) who reported rise in malonaldehyde (biomarker used to measure stress in farm animals) in the blood of broilers reared in environment of high ammonia production supports this assertion. So it could be that the control birds were stressed more compared to treated groups. Report work of Wei et al. (2012) affirms the assertion that ammonia gas is a stressor when observed a decrease in antioxidant capacity in broilers exposed to high ammonia production. Also, Curtis et al. (1975) reported rise in level of enzyme called lactate dehydrogenase (LDH) in the blood of broilers as a result of exposure to high atmospheric ammonia. This implies that some organs that play roles in metabolism can be injured and in this case, weight gain will be affected.

Ammonia negatively affect weight gain in birds as observed in control birds could also be attributed to inflammatory effect of ammonia in bird's gastrointestinal tracts. Inflammation of digestive organs such as small intestines affects nutrient digestibility and absorption and consequently feed conversion ratio is affected negatively. Low body weight gain and poor feed conversion ratio observed in control birds agrees with Miles et al., (2004) who reported poor feed conversion ratio and body weight gain in broilers reared in high ammonia production. Li et al. (2014) who observed reduction in average daily weight gain and average daily feed intake in broilers reared in an environment with high ammonia production was in tandem with result of this research work. Ammonia gas can also disrupt the usual organ roles in animals and bring about mitochondrial injury within the mucosa of gastro-intestinal tract and consequently, this will negatively affect energy metabolism and general performance of birds.

\section{Effect of different levels of zeolite treatment on chemical compositions of broiler litter during the starter and finisher growth phase}

Table 6 and 7 shows the chemical compositions of litter treated with varying levels of zeolite during the starter and finisher growth phases. Highest $(P<0.05)$ ammonia production was recorded in treatment $A$ (control), while the lowest $(P<0.05)$ ammonia production was recorded in treatment group litter. This could be as a result of differences recorded in moisture and $\mathrm{pH}$ levels among the treatments during the experimental periods. Ordinarily, uric acid which is a waste product from the birds does not smell, but its degradation by uricase (Nahm, 2003), an enzyme synthesized by litter microbes together with other nitrogen containing compounds in the litter leads to the production of ammonia and this is enhanced when litter moisture is high and at litter $\mathrm{pH}$ above 7 (alkalinity), while decrease in litter $\mathrm{pH}$ (acidity) discourages ammonia production because acidic environment is detrimental to microbial proliferation and activities that 
are responsible for ammonia production from the litter. Moisture is highly implicated in ammonia production from the litter (Elliott and Collins, 1982). Reece et al. (1979) reported that ammonia volatilization can be decreased when the litter $\mathrm{pH}$ falls below 7 , while it is deeply enhanced when $\mathrm{pH}$ of the litter is above 8 . Degradation or breakdown of uric acid is mainly enhanced under alkaline litter state (Rappet and Muller, 2005). Effect of enzyme called uricase which catalyzes the degradation or breakdown of uric acid gets to utmost at pH of 9. Increased litter pH (high alkalinity) presents best environment for the activities of bacteria, viral and parasitic organisms in the litter.

So, increased $(P<0.05)$ level of ammonia, ammonium nitrate, ammonium sulfate, volatile fatty acid and decreased $(P<0.05)$ level of uric acid, nitrogen and ash values (Table 6 and 7) recorded in control treatment could be attributed to the increase in $\mathrm{pH}$ and moisture contents of its litter. High microbial putrefaction must have been taken place in the control treatment.

However, in treatment group, their values of ammonia, ammonium nitrate, ammonium sulfate and volatile fatty acids litter content decreased significantly as the level of zeolite in the litter increased. This may be attributed to the aptitude of zeolite in reducing litter moisture (Schneider et al., 2016) and pH which are major culprits in ammonia production. The observed moisture reduction in the treatment group (Table 6 and 7 ) could be responsible for the significant reduction in the value of their ammonia, ammonium nitrate, ammonium sulfate and volatile fatty acids litter content. Reduced ammonia production observed in zeolite treated litter in this work is in an agreement with both the works of (Zimmermanni, 2014; Li et al. (2008) who treated litter with zeolite and recorded reduced ammonia production. Decreased ammonia production recorded in zeolite treated litter in this work also agrees with the findings of Nakaue et al., (1981) who observed diminution in the level of ammonia production in the poultry house when litter was treated with zeolite and agrees with the findings of (Eleroglu and Yaicin, 2005) who reported reduction in ammonia production from the litter when zeolite was used for litter amendment. The findings of Amon et al., (1997) who reported huge rise in level of ammonia when litter was treated with zeolite is not in tandem with the results of this present work. However, the huge rise in ammonia level when zeolite was applied to the litter as reported by (Amon et al., 1997) could be attributed to the type of zeolite used because aluminum and silicon ratio in zeolite affect its acidity or alkalinity. The higher the aluminum to silicon ratio in zeolite, the higher the reductive effect on litter $\mathrm{pH}$.

\section{Effect of different levels of zeolite treated litter on microbial load during the starter and finisher growth phase.}

The results of the effect of litter treated with varying levels of zeolite on litter microbial load during the starter and finisher phase are presented in Table 8 and 9 respectively. From the results, values of total viable count, Coli forms and Mold counts recorded in treatment $A$ (control) were significantly $(P<0.05)$ higher than the values recorded in zeolite treated litter. The increased $(P<0.05)$ total viable count, coli forms and mold recorded in control compared to the values recorded in treatments with zeolite inclusion can be linked to the variation in their litter moisture and $\mathrm{pH}$. High litter moisture and $\mathrm{pH}$ (alkalinity) encourages the proliferation and activities of the litter microbes. From the results of the litter chemical analysis presented on Table 6 and 7, control litter recorded the highest $(P<0.05)$ moisture and $\mathrm{pH}$ values. This affirms the observed increase $(P<0.05)$ in microbial load values in control litter. Moisture affects fecal coli forms survival. The higher the litter $\mathrm{pH}$ (alkalinity) and moisture of the litter, the higher the microbial number and activities. This implies that, litter alkalinity ( $\mathrm{pH}>7$ ) favors the proliferation and activities of litter microorganisms than when the litter is acidic $(\mathrm{pH}<7)$. High moisture content of litter encourages proliferation of the litter microbes than when it is low (Elliott and Collins, 1982). In zeolite treated litter, there was an observed decrease $(P<0.05)$ in litter microbial load (total viable counts, coli forms and mold) as the level of the zeolite in the litter increased. Treatment of litter with zeolite helps to reduce the litter moisture (Schneider et al., 2016) and pH and consequently, making the litter environment less favorable for microbial proliferation and activities. Reduction in litter pH creates an acidic environment that is detrimental to the litter microbial growth and putrefaction in the litter. This affirms the major reason why microbial load values observed in zeolite treated litter were significantly $(P<0.05)$ the lowest and highest in the control litter.

\section{Declarations}

\section{Funding}

The authors declare that no fund, grant or other support were received during the preparation of this manuscript.

\section{Conflict of interest}

The authors declare no competing interest.

\section{Ethics approval}

The experiment was carried out in accordance with the provisions of the Ethical Committee on the use of animals and human for biomedical research of the University of Nigeria Nsukka (2006)

\section{Consent to participate}

The authors declare that have participated in the experiment as mentioned in authors contribution section. 


\section{Consent of publication}

The authors declare that they have no conflict of interest for this publication..

\section{Availability of data and material transparency}

The data set generated during and/ or analyzed during the current study are available from the corresponding author on reasonable request.

\section{Code availability}

Not applicable

\section{Author's contributions}

Ezenwosu: Designed the study, collected data, and prepared the manuscript. Onyimony A.E: Supervised the study, Ude V.C and Osita C.O: analyzed the data, interpreted and prepared the table, Anizoba N. W and Nwoga C.C: Handled the microbial laboratory of the study. All the authors eventually read and approved the final manuscript.

\section{References}

1. Adene, D. F., (1989). An appraisal of the health management problems of rural poultry stock in Nigeria. Proceedings of the International Workshop on Rural Poultry in Africa. November 13-16, 1989, Ilelfe,Nigeria, pp: 989- 999.

2. Altan, A., Altan, O., Alçiçek, A., Nalbant, M. \& Akbaş, Y. (1998). Utilization of natural Zeolite inpoultry. I. Effects of adding zeolite to litter on broiler performance, litter moisture and ammonia concentration. J. Agr. Fac. Ege Univ. 35, 1-3.

3. Amon, M., M. Dobeic, R. W. Sneath, V. R. Phillips, T. H. Misselbrook, and B. F. Pain. (1997).A farmscale study on the use of clinoptilolite Zeolite and Deodorase for reducing odour andammonia emissions from broiler houses. Biores. Technol. 61:229-237.

4. Apsimon.H, M.Kruse, and J.N.B. Bell.(1987). Ammonia emission and their role in aciddeposition.Atmos.Environ.21:1939-1946.

5. Association of Official Analytical Chemist (AOAC). 2006.Official Methods of Analysis.18 ${ }^{\text {th }}$ ed.Washington, DC.AOAC.

6. Aziz, T. H and John Barnes. (2009).Harmful effect of ammonia on birdsWorld Poult, 26 (3),

7. Beker, A., S. L. Vanhooser, J. H. Swartzlander, and R. G. Teeter. (2004). Atmospheric ammoniaconcentration effects on broiler growth and performance. J. Appl. Poult. Res. 13:5-9.hallengeand physical damage due to increased NH3 concentration.

8. Breinholt, K. A; Gowen, F.A;Nwosu,C.C.(1981).Influence of environment and animalfactors day and night grazing activity of imported Holstein Friesan cows in the humidlowland tropics of Nigeria.Trop.Anim.Prod.6:4.

9. Bujnak, L. et al. Effects of zeolite supplementation on some fermentation process characteristicsof growing pigs. Acta Fytotechnica Zootechnica, v.18, n.3, p.63-65, 2015. Available from: .Accessed: Jun.21, 2016. doi: 10.15414/afz.2015.18.03.63-65.

10. Curtis, S.E., Anderson, C.R., Simon, J., Jensen, A.H., Day, D.L., Kelley K.W. (1975). Effects ofaerial ammonia, hydrogen sulfide and swine-house dust on rate of gain and respiratory-tractstructure in swine. J Anim Sci, 41 (3), pp. 735-739.

11. Duncan, D.B. (1955). New Multiple Range Test. Biometrics 11:1-42.

12. Eleroglu H, and H. Yalcin. (2005). Use of natural zeolite supplemented litter increased broiler production. S. Afr. J. Anim. Sci. 35:90-97.Elliott, H; Collins, N. (1982). Factors affecting ammonia release in broiler houses. Trans ASA25:413-418.

13. FAO (2010). Chicken Genetic Resources Used in Small holder Production Systems andOpportunities for their Development. FAO Small holder Poultry Production Paper, No. 5.Rome: Food and AgricultureOrganization.

14. Farrell, D. (2013). The role of poultry in human nutrition.http://www.fao.org/docrep/013/al709e/al709e00.pdf Accessed 10 April 2015.

15. Kristensen, H. H., and C. M. Wathes. (2000). Ammonia and poultry welfare: A review. Worlds Poult. Sci. J. 56:235-245

16. Li H, Xin H, Liang Y. (2008).Burns RT. Reduction of ammonia emissions from stored layinghen manure through topical application of zeolite, Al+Clear, Ferix-3, or poultry litter treatment.Journal of Applied Poultry Research; 17(4):421-431.

17. Li, C. Lu, Q.P.,Tang,X.F., Zhang,J, Z., Ding, Z.M.,Zhang,H.F. (2014). Influence of ammoniaconcentration on growth performance and meat quality of broilers .Sci Agric Sin, 47 (22) (2014),pp. 4516-4523.

18. Mata-Alvarez J, Dosta J, Romero-Güiza MS, Fonoll X, Peces M, Astals S (2014) A criticalreview on anaerobic co-digestion achievements between 2010 and 2013. Renew Sustain EnergyRev 36:412-427

19. Meda, A., M. Hassouna, C. Aubert, P. Robin. and J.Y. Dourmand, (2011). Influence of rearingconditions and manure management practices on ammonia and greenhouse gas emissions frompoultry houses. World's Poult. Sci. J., 67: 441-445.

20. Miles,D .M., Branton, S.L.,Lott, B.D. (2004).Detrimental effect of atmospheric ammonia onmodern commercial broiler. Poult.Sci.83,1650-1654.

21. Miles, D. M., S. L. Branton, B. D. Lott, and J. D. Simmons. (2002). Quantified detriment ofammonia to broilers. Poult. Sci. 81(Suppl. 1):54. (Abstr.)

22. Moore Jr, P.A., T.C. Daniel, D.R. Edwards, and D.M. Miller. (1996). Evaluation of chemicalamendments to reduce ammonia volatilization from poultry litter. Poult. Sci., 75: 315-320 
23. Munk, B., Guebitz, G.M., Lebuhn, M, (2017) Influence of nitrogen-rich substrates on biogasproduction and on the methanogenic community under mesophilic and thermophilic conditions.Anaerobe 46, 146e154. https://doi.org/10.1016/ j.anaerobe.2017.02.015

24. Nahm, K.H. (2003). Evaluation of the nitrogen content in poultry manure. Worlds Poult Sci J59:77-88. doi: 10.1079/WPS20030004.

25. Nakaue,H.S;J.K.Koelliker, and M.L.Person.(1981). Studies with clinoptilolite in poultry.II.Effectof feeding broilers and direct application of clinoptilolite(Zeolite) on clean and reused broilerlitter on broiler performance and house environment.Poult.Sci.60:1221-1228.

26. Obayelu,A.E (2010).Assessment of The Economic And Environmental Effects of OdorEmission from Mechanically Ventilated Livestock Building in Ibadan Oyo StateNigeria.International journal of science and nature VOL.1(2) 113-11.

27. Obi, I.U. (2002). Statistical methods of detecting differences between treatments means andresearch methodology issues in laboratory and field experiments. $2^{\text {nd }}$ Ed.Express Pub.Ltd.Enugu.Pp13-21.

28. Okonkwo, W. I and Akubuo, C. O. (2007). Trombe wall system for poultry brooding. Int. J.Poultry Sci.6冈125-130.

29. Pearson, D. A. (1976). The Chemical Analysis of Foods (7th ed) Churchill and living stone,Eduinburgh, London pp 355 - 356.

30. Ratner, M.A. and Ratner, D. (2003). Nanotechnology: A Gentle Introduction to the Next Bigldea. Prentice Hall Professional.E-book in https://books.google.co.ls/books?

id=m9Tn_V4an28C\&printsec=frontcover\&dq=Nanotechnology:+A+Gentle+Introduction+to+the+Next+Big+ldea\&hl=en\&sa=X\&ved=0CBsQ6AEwAGoVChMlc dea\&f $=$ false.$h t m l$.

31. Reece,F.N; B. J. Bates, and B. D. Lott . (1979). Ammonia control in broiler houses, PoultryScience, vol. 58, pp. 754-755, 1979.

32. Sanjay, S., W. Philip and P. James, (2006). Poultry litter amendments. North CarolinaCooperative Extension Service Bull., pp: 1-6.

33. Sarıca, M., Saylam, S.K., Öner, F. \& Karçay, N., (1996). The effect of Zeolite supplementedlitter on the broiler performances and litter properties. Anim. Cong. '96, İzmir. pp. 346-352.

34. Schneider A.F, De Almeida D.S, Yuri F.M, Zimmermann O.F, Gerber M.W, Gewehr C.E.(2016).Natural zeolites in diet or litter of broilers. Br. Poult. Sci; 57(2):257-263.

35. SPSS (2003). Statistical Package for social Sciences. Window Version 8.0

36. St-Pierre, N.R, Cobanov B, Schnitkey, G.X.(2003). Economic Losses from Heat Stress by US LivestockIndustries. J Dairy Sci $2003 ; 86(E)$ :E52-E77. https://doi.org/10.3923/ijps.2013.289.297.

37. Ullman, J. L., S. Mukhtar, R. E. Lacey, and J. B. Carey. (2004). A review of literatureconcerning odors, ammonia, and dust from I kappa B kinase and ameliorates acute murinecolitis. Inflamm. Bowel Dis.12:1152-1161.

38. United Nations Department of Economic and Social Affairs: Population ～Division. (2004): 3, 14.Retrieved July 3, 2010.

39. United Nations Development Programme (2006). Socio-economic Impact of Avian Influenza inNigeria, Abuja.

40. United Nations (2017) Resolution adopted by the General Assembly on 6, July 2017, work of the

41. Statistical Commission pertaining to the 2030 Agenda for Sustainable Development(A/RES/71/313-Archived, 28 November 2020 at the Wayback Machine)

42. Van Breemen, N., Burrough, P. A., Velthorst, E. J., van Dobben, H. F., de Wit, T., and Reijinders, T. B. (1982). Soil acidification from atmospheric ammonium sulphate in forest canopy throughfall. Nature 299, 548-550. doi: 10.1038/299548a0.

43. Wang Z.P., Gao T., Jiang Z.Q., Min Y.N., Mo J.X., Gao Y.P. (2014) Effect of ventilation ondistributions, concentrations, and emissions of air pollutants in a manure-belt layer house. J.Appl. Poult. Res;23:1-10. doi:10.3382/japr.2014-01000.

44. Wei,F.X ., Xu, B., Sa, R.N.,Li,S.Y., Liu,F.Z., Sun,Q.Y. (2012). The effect of ambient relativehumidity and ammonia on antioxidant capacity and meat quality of broiler chickens. Acta VetZootech Sin, 43 (10) pp. 1573-1581

45. Wheeler, E.F., K.D. Casey, J.L. Zajaczkowski, P. Topper, R.S. Gates, H. Xin and H, Liang,(2004). Seasonal ammonia emission variation among twelve U.S broiler houses. ASAE paper 044105. Am. Soc. Agric.

46. World meters RTS algorithm (2019).Elaboration of the latest United Nations data

47. Zimmermann,O.F,(2014). Zeólitas naturais na alimentação de suínos em crescimento eeterminação. 86f. DISSERTAÇÃo (Mestrado em Ciência Animal) Curso do Programa deósgraduação em Ciência Animal, Universidade do Estado de Santa Catarina, SC.fvo Availablefrom: . Accessed: Dez. 17, 2014.

\section{Figures}


Figure 1

\section{Chemical replica of a zeolite complex stru}

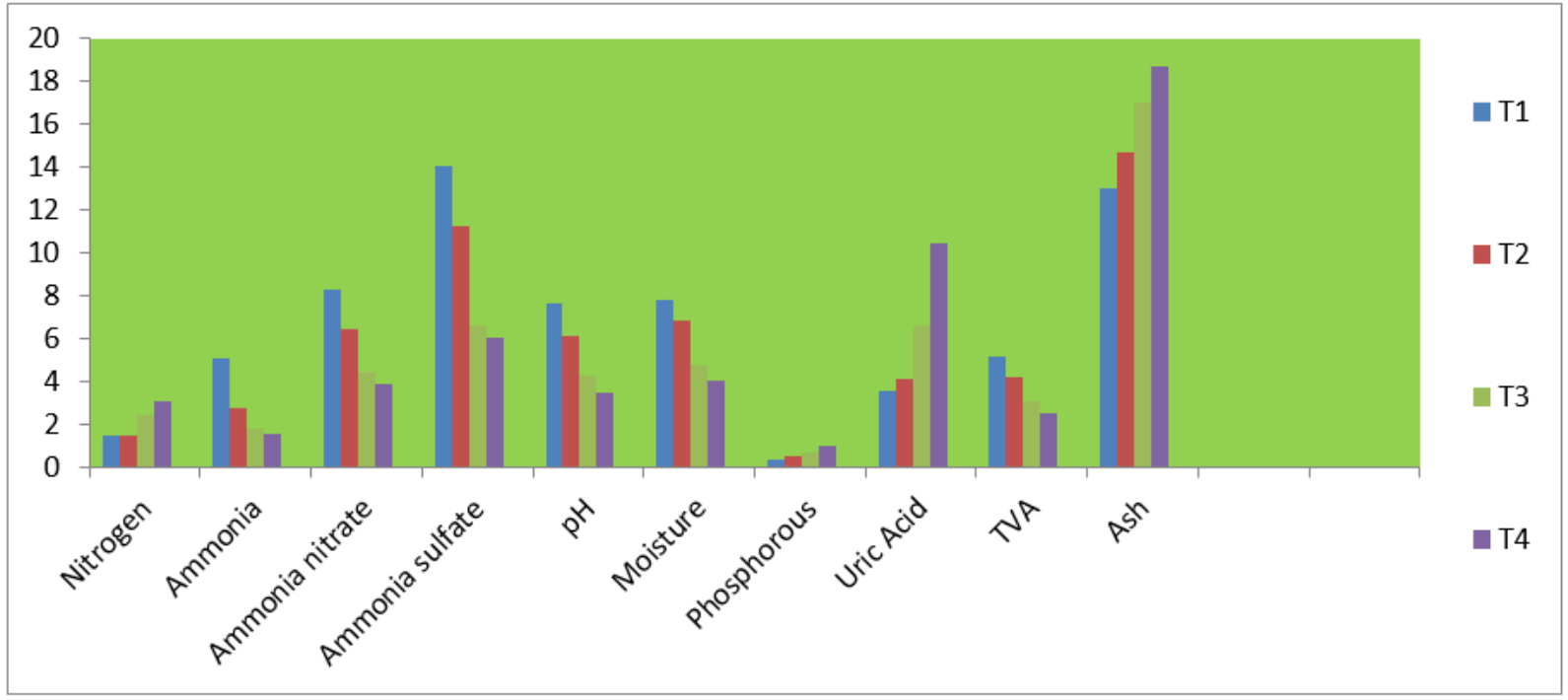

Figure 2

Bar chat representing the result of the Chemical compositions of different levels of zeolite treated litter during the starter

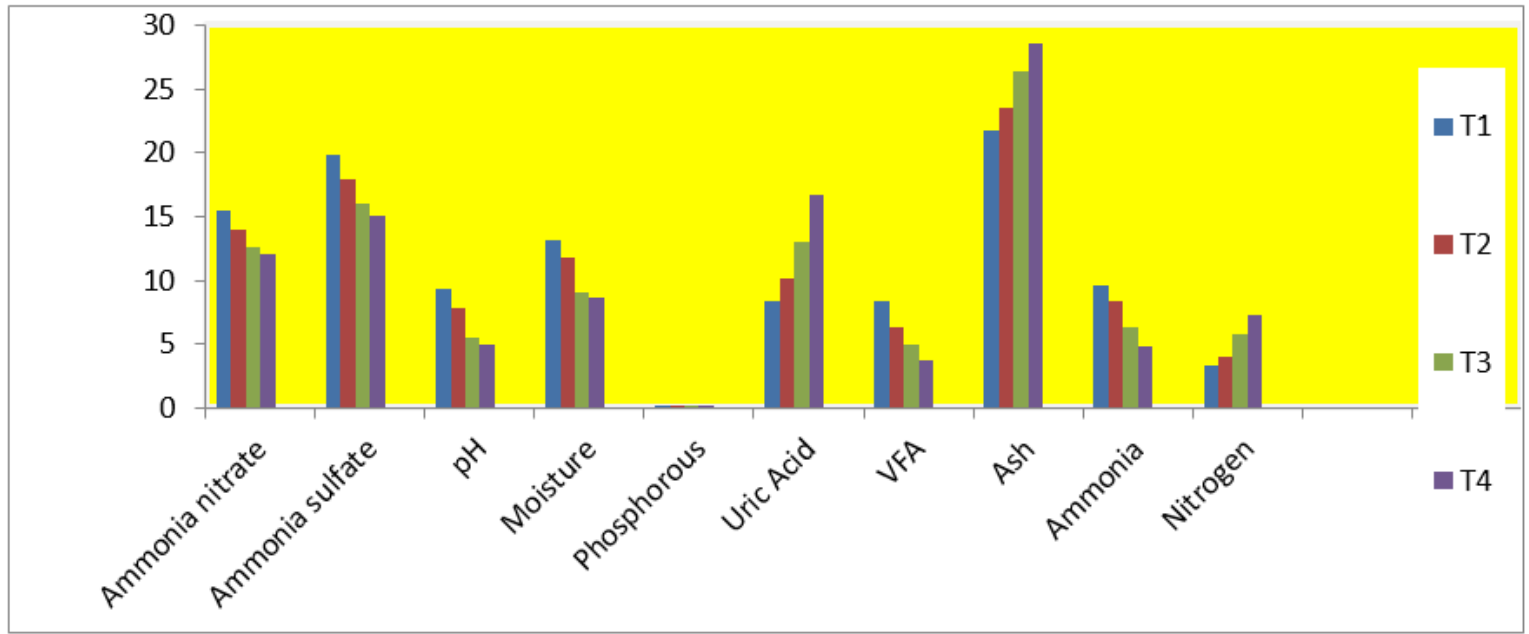

\section{Figure 3}

Bar chat representing the result of the Chemical compositions of different levels of zeolite treated litter during the finisher growth phase. 


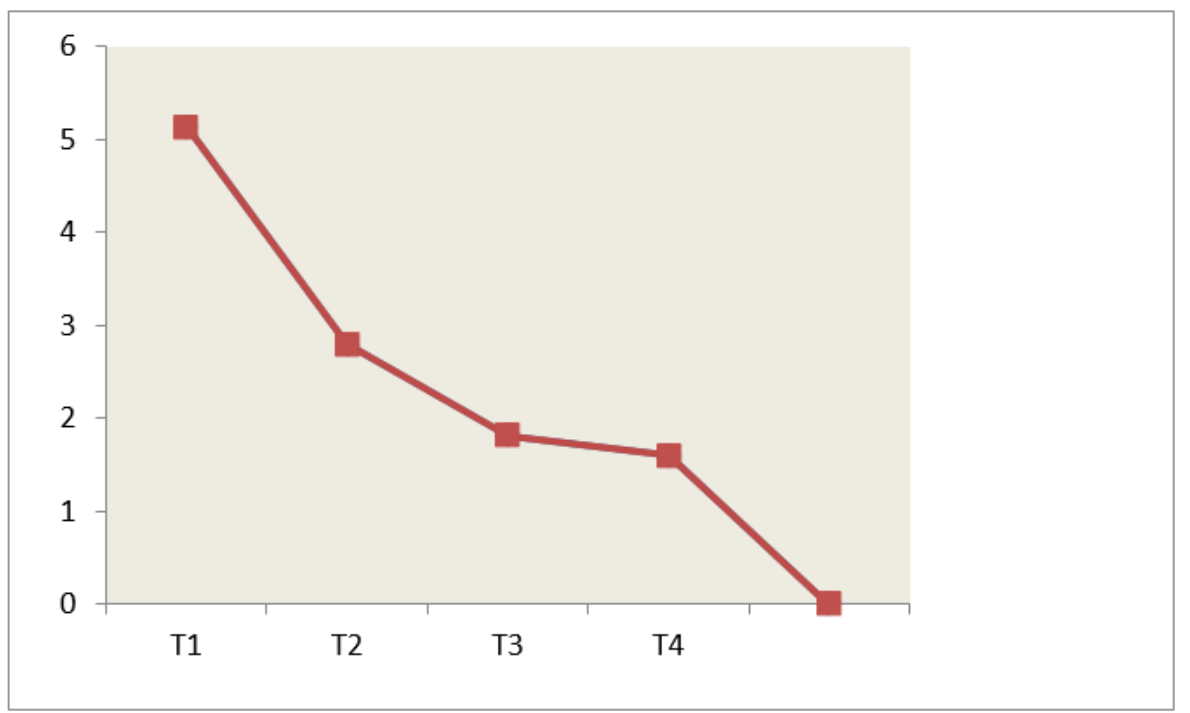

\section{Figure 4}

The mean plot of the litter ammonia content of the various treatments during the starter phase

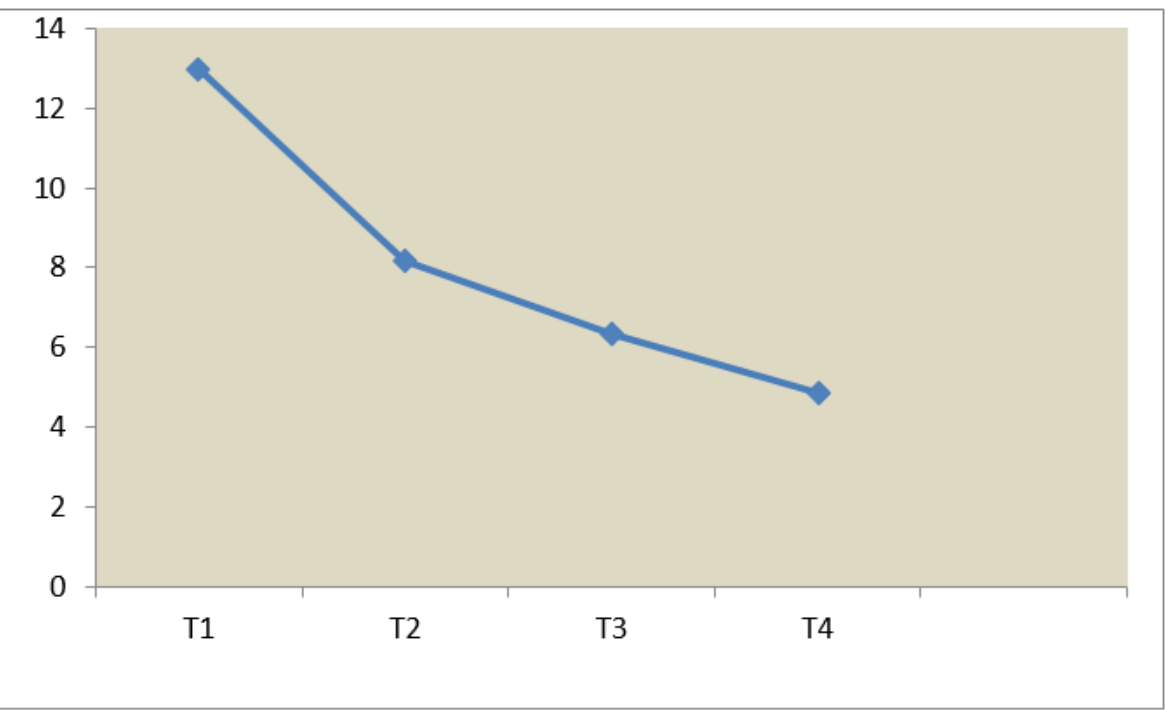

\section{Figure 5}

The mean plot of the litter ammonia content of the various treatments during the finisher phase 